\title{
Is cut-stump and girdling an efficient method of black cherry Prunus serotina Ehrh. eradication?
}

\author{
Anna Otręba $a^{1}$, Katarzyna Marciszewska ${ }^{2} \bowtie$, Daria Janik $^{2}$ \\ ${ }^{1}$ Kampinos National Park, Tetmajera 38, 05-080 Izabelin, Poland \\ ${ }^{2}$ Warsaw University of Life Sciences - SGGW, Department of Forest Botany, Nowoursynowska 159, 02-776 Warsaw, \\ Poland, phone: +48 22 5938026, e-mail: katarzyna.marciszewska@wl.sggw.pl
}

\section{Abstract}

Efforts to prevent the invasion of black cherry Prunus serotina Ehrh. have a long history in Western Europe. However, effective methods of eliminating it that do not bear negative side effects for ecosystems have not yet been developed. Mechanical methods are the first choice in environmentally sensitive areas. In this study, we aimed to find answers to the questions: does the application of cutting at a height of $1 \mathrm{~m}$ from the ground limit the sprouting capacities of black cherry? And, is stem girdling an effective method of eliminating black cherry? The study was carried out in the Kampinos National Park, on two mixed pine forest plots with undergrowth of black cherry. Three mechanical methods of elimination were applied: cut-stump at the base, cutting at a height of $1 \mathrm{~m}$ above the ground and girdling of the stem at a height of ca $1 \mathrm{~m}$ above the ground. In both locations, 225 trees were treated, at three different dates corresponding with three different phenological phases of black cherry development. The evaluation of effectiveness of treatments was based on the sprouting capacity of the tree afterwards, which included: the number of generated sprouts, the length of three longest sprouts, dry mass of sprouts, and the assessment of tree survival rate. It was discovered that girdling is a significantly more effective method of control than ground-level cut-stump or cutting at a height of $1 \mathrm{~m}$ above the ground in the conditions of central Poland. However, in the season of treatment, even though recurring sprouts were removed, only a part of the girdled trees died (24\% to 54\%). There is a slight difference between the sprouting response of cutting at a height of $1 \mathrm{~m}$ above the ground ( $4 \%$ to $24 \%$ of dead trees) and the basal cut-stump method ( $0 \%$ of dead trees).

\section{KeY WORDS}

mechanical methods of elimination, mixed pine forests, invasive plants, protected natural areas, sprouts

\section{INTRODUCTION}

The prevention of biological invasions is an important task faced by the environmental protection services, following the implementation of Convention on Biological Diversity (CBD 1992) and Regulation (EU)
No 1143/2014 of the European Parliament and Council on 22 October 2014. Such work requires a thorough knowledge of expansion of the invasive species, its biology and ecology, and the effectiveness of methods of elimination. Black cherry Prunus serotina Ehrh., originating in North America, is one of the 100 most 
expansive organisms in Europe, where in many countries (e.g., the Netherlands, Germany, Denmark) it is referred to as a 'wood weed' (DAISE; Starfinger 1997; Vanhellemont 2009). It occurs in the whole area of Poland (Tokarska-Guzik 2005). It has been inventoried in an area of ca 100,000 ha of forests managed by the State Forests National Forest Holding (PGL LP), which constitutes $1.4 \%$ of their total area (Bijak et al. 2014). The invasion of black cherry has also expanded in protected areas. It occurs in 10 out of 23 Polish national parks, and it is the most frequently combatted species there (Najberek and Solarz 2011; Bomanowska et al. 2014).

Even though the elimination of black cherry has a long history in Western Europe, efficient methods that would not bear negative side effects for ecosystems have not been developed (Muys et al. 1992; Starfinger et al. 2003). It is well known that elimination is costly and time consuming, and its results can be lost through discontinuation of procedures, which leads to a reinvasion of the species. High effectiveness is shown by chemical controls, including, for example, the application of substances containing glyphosate (Van den Meersschaut and Lust 1997; Csiszár and Korda 2015). However, the application of chemical substances negatively impacts many components of the environment, and they should not be applied in protected regions (Tokarska-Guzik et al. 2012). On terrain that is especially environmentally sensitive, it is necessary to limit to mechanical methods, among which the most commonly applied is basal cutstump. This is the least labour-intensive method, but it is also ineffective, as many sprouts shoot off from the remaining stump (Starfinger et al. 2003; Halarewicz 2012; Namura-Ochalska 2012; Annighöfer et al. 2012). This occurs because black cherry displays a high regeneration capacity after damage, which is exploited in its natural habitats for the sake of forest regeneration (Husch 1954; Marquis 1990). For this reason, other methods are sought for practical uses, such as cutting the stump at a higher level, girdling and the introduced underplanting of the cultivated seedlings (e.g., Otręba et al. 2014; Krzysztofiak and Krzysztofiak 2015; Namura-Ochalska and Borowa 2015; Demeter and Lesku 2015). Experiments with application of various methods of elimination, including mechanical methods, have been carried out so far in Belgium and Italy (Van den Meersschaut and Lust 1997; Annighöfer et al. 2012). The experi- ments indicate a high effectiveness of girdling, falling just below that of chemical methods of control.

The aim of this study is to ascertain whether, in the habitat conditions of central Poland, cutting stumps at the height of ca $1 \mathrm{~m}$ from the ground limits the sprouting capacity of black cherry, and if girdling of the stem is an effective method of eliminating black cherry.

The field experiment was carried out in the Kampinos National Park, where black cherry is one of the most frequent alien tree species, and where the scope of work aimed at its limitation spans more than 400 ha per year (Otręba et al. 2014). Due to its high environmental value, the Kampinos forest is protected as a national park and as a part of the Natura 2000 and Biosphere Reserve programmes. The obtained results will enable development of a more effective and efficient method of mechanical elimination of black cherry - a species alien among the European flora.

\section{MAterial AND MEthods}

\section{Study sites location and characteristics}

The Kampinos National Park, located in the central Mazovian Lowland, is nearly entirely situated in the Warsaw Valley, with only its southern and eastern fragments reaching the Lowicz-Błonie Plain and the Warsaw Plain, respectively. The main characteristic of the Park's landscape is the presence of belts of dunes and swamps formed in the proto-valley of the Vistula River. Forests cover $73 \%$ of the Park's $385 \mathrm{~km}^{2}$ area. The coniferous pine forests of various levels of soil fertility, moisture and anthropogenic transformation dominate in the Park (Andrzejewska et al. 2010). The climate is temperate, with a prevalence of continental characteristics over Atlantic ones. The mean yearly temperature is $7.7^{\circ} \mathrm{C}$, the vegetation period lasts 185 days, and the mean yearly precipitation level is $547 \mathrm{~mm}$ (Andrzejewska 2003). The year 2015, when the experiment was carried out, was exceptionally dry and warm (Andrzejewska, unpubl.).

\section{Plot design and characteristics}

The study area was located in the eastern part of the Kampinos National Park, in the protection district of Laski, on two plots: at Sieraków (N - 52,30290, E - 20,84810), forest division number 345, and Lipków ( $\mathrm{N}-52,28334$, E - 20,81810), division no. 185 . The criteria of uniform- 
ity of habitat conditions, species composition, and vertical canopy structure within each location were used for the selection of study plots. The similarity of locations was not taken into account. Plots were characterised by the presence of abundant undergrowth forming a lower shrub layer of black cherry that was not yet eliminated. Both plots are located at the outskirts of the forest complex. In Sieraków, the plot borders private woods and lands belonging to the Laski village; in Lipków it borders a built-up area of the Hornówek village. Both locations are situated at the edge of the Warsaw Plain.

The environmental profile of the study plots was based on appraisal descriptions (Protection Plan of the Kampinos National Park, KPN 2002) that were then verified in the field. The Sieraków canopy is characterised by a three-layer structure and two-generational nature. The higher stratum of the canopy is dominated by pedunculate oak, silver birch and Scots pine, the last reaches the age of 175 or 94 years. The lower layer is composed mainly of black cherry, reaching a cover of ca $30 \%$. The floor is dominated by a neophyte, Impatiens parviflora DC., accompanied by species of nitrophilous ecotones: Moehringia trinervia (L.) Clairv., Geranium robertianum L., Alliaria petiolata (M.Bieb) Cavara et Grand and scarce coniferous species (diagnostic species, in the syntaxonomy after Matuszkiewicz 2001). According to the Protection Plan (2002), the forest type is described as a fresh mixed coniferous forest formed on Brunic Arenosol Albic on sand, with traces of post-agrarian character.

The plot in Lipków is covered by the Scots pine canopy aged 79 years, with an admixture of silver birch and sparse pedunculate oaks. Its abundantly formed (70\% of cover) lower layer consists mostly of two species: black cherry and Norway maple. The floor, reaching on a significant area only up to $20 \%$ of cover, is dominated by Rubus caesius L., accompanied by Vaccinium myrtillus L., Dryopteris carthusiana (Vill) H.P. Fuchs and Moehringia trinervia (L.) Clairv. According to the Protection Plan (2002), the forest type is described as fresh mixed forest formed on Haplic Podzol on sand.

\section{Premises of the experiment}

The study to assess the effectiveness of given methods of mechanical elimination of black cherry was carried out during the vegetation season of 2015, in the form of an experiment in natural conditions. Overall, 450 trees were selected, 225 in each of the two locations: Sieraków and Lipków. The trees occupied ca 0.6 ha in each case.

Three types of procedures of mechanical elimination of black cherry were applied: 1) cut-stump at the base level with a chain saw (this commonly used method is a kind of reference probe); 2) cutting the tree at a height of ca $1 \mathrm{~m}$ above the ground level with a chain saw; and 3) girdling by removal of the bark, phloem and cambium at a width of ca $20 \mathrm{~cm}$ around the whole circumference of the stem at a height of ca $1 \mathrm{~m}$ above ground level with a draw knife.

The procedures were carried out three different times, each time on 25 trees in each location. The dates when the cuts were performed corresponded to different phenological phases of the life cycle of black cherry and to different vegetation conditions. The cuts were performed on April 8th (which reflects early spring and the beginning of the vegetation period), then on June 2nd (which corresponds to late spring and peak of black cherry's blooming season), and on July 29th (which corresponds to summer and the formation of black cherry's fruits).

The trees subjected to procedures of mechanical elimination were directly adjacent to one another in the terrain, which balanced the impacts of their microhabitat on the results of the experiment. Specimens with large crowns and at least $4 \mathrm{~cm}$ DBH were selected for the experiment. For each tree, the following measurements were taken: diameter at breast height (accurate to $0.1 \mathrm{~cm}$ ), height (accurate to $50 \mathrm{~cm}$, using a Suunto hypsometer), and length of the crown (accurate to $50 \mathrm{~cm}$, using a Suunto hypsometer). The trees were individually numbered in the field to enable their identification.

Drawing on an experiment carried out in Belgium (Van den Meersschaut and Lust 1997) for the sake of increasing the effectiveness of the procedures, an additional treatment was performed: it consisted of tearing off new sprouts and recreating girdles in the cases where stem tissues were regenerated; the removal of sprouting shoots was repeated every 8 weeks. For the trees treated first in spring, it was done three times (that is, on June 1st, July 28th and September 20th); for the trees treated in late spring, twice (on July 28th and September 20th); and for those treated in the summer, once (on September 20th). The evaluation of effective- 
ness of each procedure of elimination of black cherry was based on an analysis of the following parameters reflecting the sprouting capacity after the procedure: the number of generated sprouts, length of three longest sprouts and dry mass of generated sprout shoots. The dry mass was weighed after 48 hours of drying at a temperature of $105^{\circ} \mathrm{C}$. The sums of measurements obtained in each control were used for analysis: that is, for the early spring procedures, from three controls; for the late spring ones, from two controls; and only for the summer cuts, from a single control.

Each time, the crown-regenerating capacity of the girdled trees was assessed using a two-point scale (dead or alive). Capacity for regeneration - reflected in the percentage of dead trees in the total number of those treated by each procedure - was used for assessment of the effectiveness of each tested procedure. The stems that did not generate any sprouts by the end of the season (on September 20th) were considered dead. In the case of the girdled trees, the crowns were also dead.

\section{Statistical Analysis}

Biometric parameters and variables reflecting the sprouting capacity did not generally demonstrate a normal distribution (Shapiro and Wilk's W test) and did not meet the criterion of variation homogeneity (Levene's test). Due to this fact, the Kruskal-Wallis nonparametric multiple comparison of mean ranks test was used for all samples (Stanisz 2006), followed by pairwise comparison (post-hoc test) using Mann-
Whitney test with Bonfferoni corrected $\mathrm{p}$ values. The significance level was set to $p=0.05$. The two populations of trees from two plots were considered as independent blocks. Calculations and charts were made with the applications Past 3 (Hammer et al. 2001) and Microsoft Office Excel.

\section{Results}

\section{Biometric parameters of the trees used in the experiment}

Stem diameter at DBH, the height of trees and the length of crown are presented using a mean for all trees treated with the same procedure, regardless of the date of procedure (Tab. 1). The girth of trees at DBH ranged between $4.3 \mathrm{~cm}$ and $21.2 \mathrm{~cm}$, the height ranged from $3 \mathrm{~m}$ to $17 \mathrm{~m}$, and the crown length ranged between $0.5 \mathrm{~m}$ and $9 \mathrm{~m}$. The trees on Lipków plot were thicker and had more developed crowns than those in Sieraków, and the differences are statistically significant (Mann-Whitney's U test: DBH: $\mathrm{z}=-4,1236$, $\mathrm{p}=3,73 \mathrm{E}-05$; height: $\mathrm{z}=-1,8691, \mathrm{p}=0,0616$; crown length: $z=-3,5742, p=0,0004)$. On the other hand, the girth, height and length of crown of the treated trees within each plot did not display statistically significant differences (Kruskal-Wallis' test: DBH: Sieraków $\mathrm{H}=2.989, \mathrm{p}=0.2242$; Lipków $\mathrm{H}=1.69$, $\mathrm{p}=0.4295$; height: Sieraków $\mathrm{H}=3.246, \mathrm{p}=0.1943$; Lipków $\mathrm{H}=3.808, \mathrm{p}=0.1465$; crown length: Sieraków $\mathrm{H}=1.45, \mathrm{p}=0.4787 ; \mathrm{H}=0.4206, \mathrm{p}=0.8068)$.

Table 1. Biometric parameters of black cherry trees treated by the procedure of mechanical elimination in the Kampinos National Park

\begin{tabular}{|c|c|c|c|c|c|c|c|c|c|c|c|}
\hline \multirow{2}{*}{ Location } & \multirow{2}{*}{ Treatment } & \multirow{2}{*}{$\begin{array}{c}\text { No } \\
\text { of trees }\end{array}$} & \multicolumn{3}{|c|}{$\mathrm{DBH}(\mathrm{cm})$} & \multicolumn{3}{|c|}{ Height (m) } & \multicolumn{3}{|c|}{ Crown length (m) } \\
\hline & & & $\min$. & $\max$. & median & $\min$. & $\max$. & median & $\min$. & $\max$. & median \\
\hline \multirow{4}{*}{ Sieraków } & Cut-stump & 75 & 4.8 & 21.2 & 8.1 & 4.0 & 15.0 & 8.0 & 1.5 & 8.0 & 3.0 \\
\hline & Cut at $1 \mathrm{~m}$ & 75 & 6.1 & 18.5 & 8.2 & 4.0 & 13.0 & 8.0 & 0.5 & 7.0 & 3.0 \\
\hline & Girdling & 75 & 6.0 & 18.1 & 8.6 & 4.5 & 16.0 & 8.5 & 1.0 & 7.5 & 3.0 \\
\hline & Total & 225 & 4.8 & 21.2 & $8.3^{*}$ & 4.0 & 16.0 & $8.0^{*}$ & 0.5 & 8.0 & $3.0^{*}$ \\
\hline \multirow{4}{*}{ Lipków } & Cut-stump & 75 & 6.2 & 16.2 & 9.1 & 3.0 & 16.0 & 8.0 & 1.0 & 8.0 & 4.0 \\
\hline & Cut at $1 \mathrm{~m}$ & 75 & 5.4 & 17.0 & 9.9 & 5.0 & 17.0 & 8.5 & 1.0 & 8.0 & 3.5 \\
\hline & Girdling & 75 & 4.3 & 21.2 & 9.8 & 5.5 & 17.0 & 10.0 & 2.0 & 9.0 & 4.0 \\
\hline & Total & 225 & 4.3 & 21.2 & $9.5^{* *}$ & 3.0 & 17.0 & $8.5^{*}$ & 1.0 & 9.0 & $4.0 * *$ \\
\hline
\end{tabular}

$*_{-} *_{\text {_ }}$ pairs statistically significant at $p=0.05$. 


\section{Sprouting response of black cherry to mechanical elimination procedures}

Sprouting capacity as assessed by the number of sprout shoots generated after the procedure differed significantly with regard to the type of procedure applied (early spring treatment $\mathrm{H}=86.07, \mathrm{p}=4.45 \mathrm{E}-17$, late spring treatment $\mathrm{H}=82.91, \mathrm{p}=1.696 \mathrm{E}-16$, summer treatment $\mathrm{H}=89.19, \mathrm{p}=7.872 \mathrm{E}-19$ ) (Fig. 1). Noticeably less sprouts were recorded in the case of girdled trees, and the difference with regard to the other treatments was statistically significant in each date of application
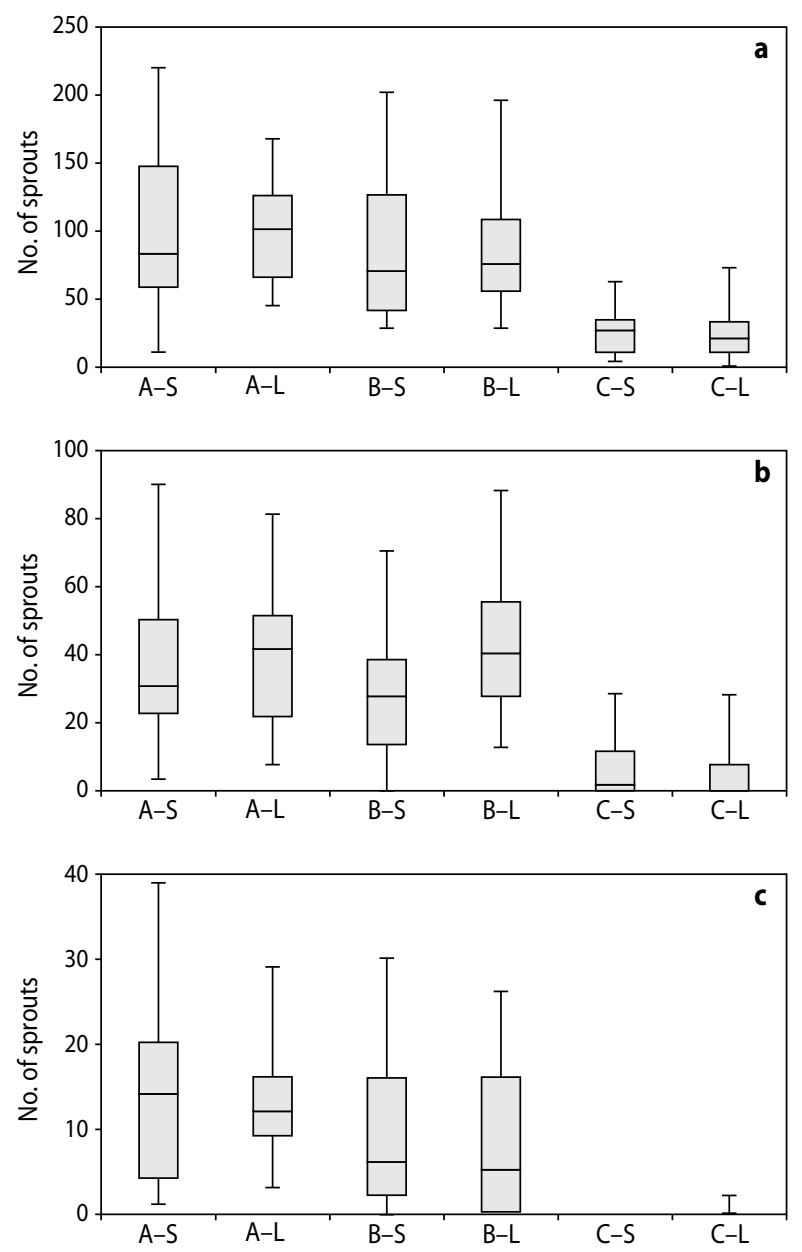

Figure 1. Total number of black cherry sprout shoots collected in the 2015 vegetation season - quartile method. Sprout generation response of cut or girdled trees: $a$ - in early spring, with three-time removal of sprouts; $b$ - in late spring, with two-time removal of sprouts; $\mathrm{c}-$ in the summer, with a one-time removal of sprouts. A = basal cut-stump; $\mathrm{B}=$ stem cut at a height of $1 \mathrm{~m}$ above the ground, $\mathrm{C}=$ stem girdling; $\mathrm{S}=$ Sieraków plot, $\mathrm{L}=$ Lipków plot at $\mathrm{p}<0.01$. Within the same treatment, no differences between plots were significant. The trees girdled in early spring (Fig. 1a) sprouted four times fewer shoots ( 25 shoots on average in both Sieraków and Lipków) than those to which cut-stump was applied (Sieraków, 103 shoots on average; Lipków, 99 shoots on average). The maximum number of sprouts recorded among the trees cut at the base was 120 (in the Sieraków plot), while it was 73 among the girdled ones (in the Lipków plot). As the date of girdling grew later, the percentage of trees generating sprouts dropped. Practically all trees
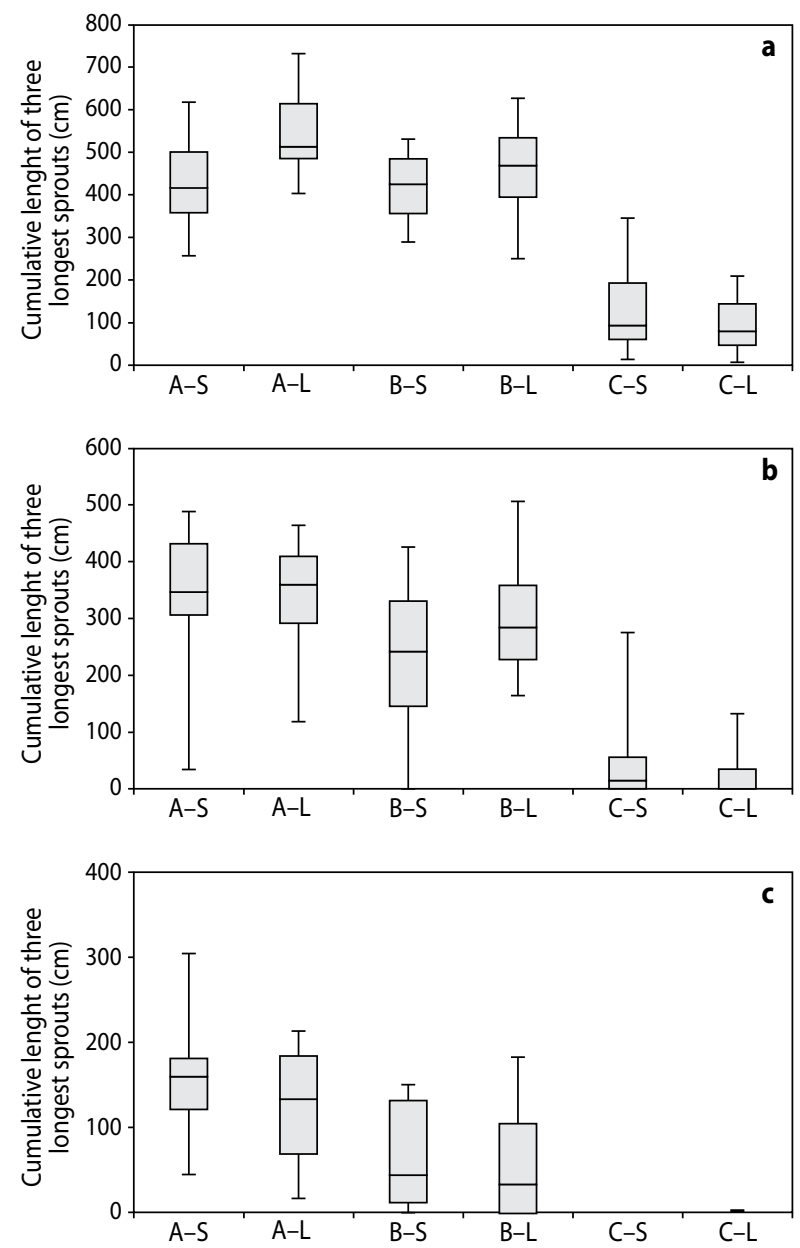

Figure 2. Total length of the 3 longest sprout shoots of black cherry collected in the 2015 vegetation season - quartile method. Sprout generation response of trees cut or girdled: $\mathrm{a}-$ in early spring, with three-time removal of sprouts; $b$ - in late spring, with two-time removal of sprouts; $\mathrm{c}-$ in the summer, with a one-time removal of sprouts. A = basal cutstump, B = stem cut at the height of $1 \mathrm{~m}$ above the ground, $\mathrm{C}=$ stem girdling; $\mathrm{S}=$ Sierków plot, $\mathrm{L}=$ Lipków plot 
girdled in the summer failed to generate sprouts $(100 \%$ for Sieraków, 96\% for Lipków) in the given vegetation season. High cuts usually (in 5 per 6 cases) resulted in generation of a smaller number of sprouts in comparison to the control basal cut-stump; however, the differences in mean values ranging between $15 \%$ and $38 \%$ were not statistically significant (Fig. 1).

Also, regarding the total length of three longest sprout shoots, girdling proved to most effectively limit the generative capacities of black cherry at all given dates of application of the procedure, on both study plots (Fig. 2) (early spring treatment $\mathrm{H}=107.5, \mathrm{p}=1.366 \mathrm{E}-21$, late spring treatment $\mathrm{H}=102.9, \mathrm{p}=1.025 \mathrm{E}-20$, summer treatment $\mathrm{H}=103.6, \mathrm{p}=5.024 \mathrm{E}-22$ ). The difference with the two other types of procedures was in all cases statistically significant at $p<0.01$. Cutting stems at a height of $1 \mathrm{~m}$ limited the lengthwise growth of the shoots in comparison to the basal cut-stump procedure, and this result was strengthened by delaying the procedure. Differences were statistically significant in four out of six variants of the procedure (i.e., for early spring cuts in Lipków, for late spring cuts in Sieraków, and for the summer cuts on both study plots).

Girdling proved to be the procedure that most significantly limited the biomass of generated sprouts, regardless of the date of procedure (Fig. 3). Its effect differed statistically from that of the other two methods at $p<0.01$. The dry mass of sprout shoots after girdling in early spring (Fig. 3a) was 13 times smaller than after basal cut-stump in the study plot in Sieraków (82.7 $\mathrm{g}$ on average after basal cut-stump and $6.5 \mathrm{~g}$ after girdling) and 25 times smaller in the study plot in Lipków (98.8 g on average after basal cut-stump and $3.9 \mathrm{~g}$ after girdling). The effectiveness of the basal cut-stump procedure and stem cutting at the height of $1 \mathrm{~m}$ above ground in early spring was similar to the analysed measure. However, as the application of procedure was delayed, the effectiveness of cutting at a height of $1 \mathrm{~m}$ rose. It gave a statistically significantly different result from the one obtained from basal cut-stump after the summer application of the procedures (Fig. 3c). For each date of the procedure and study plot, the mean values of the dry mass of sprouts after cutting at the height of $1 \mathrm{~m}$ were lower by $2 \%$ to $67 \%$ than the mean values obtained from the application of basal cut-stump.

The block effect did not occur in most analyses; that is, the differences in obtained values did not vary with relation to the given plot. A statistically significant difference between the results from Sieraków and Lipków was recorded in only 2 out of 27 cases (Fig. 2a, A and B treatment).
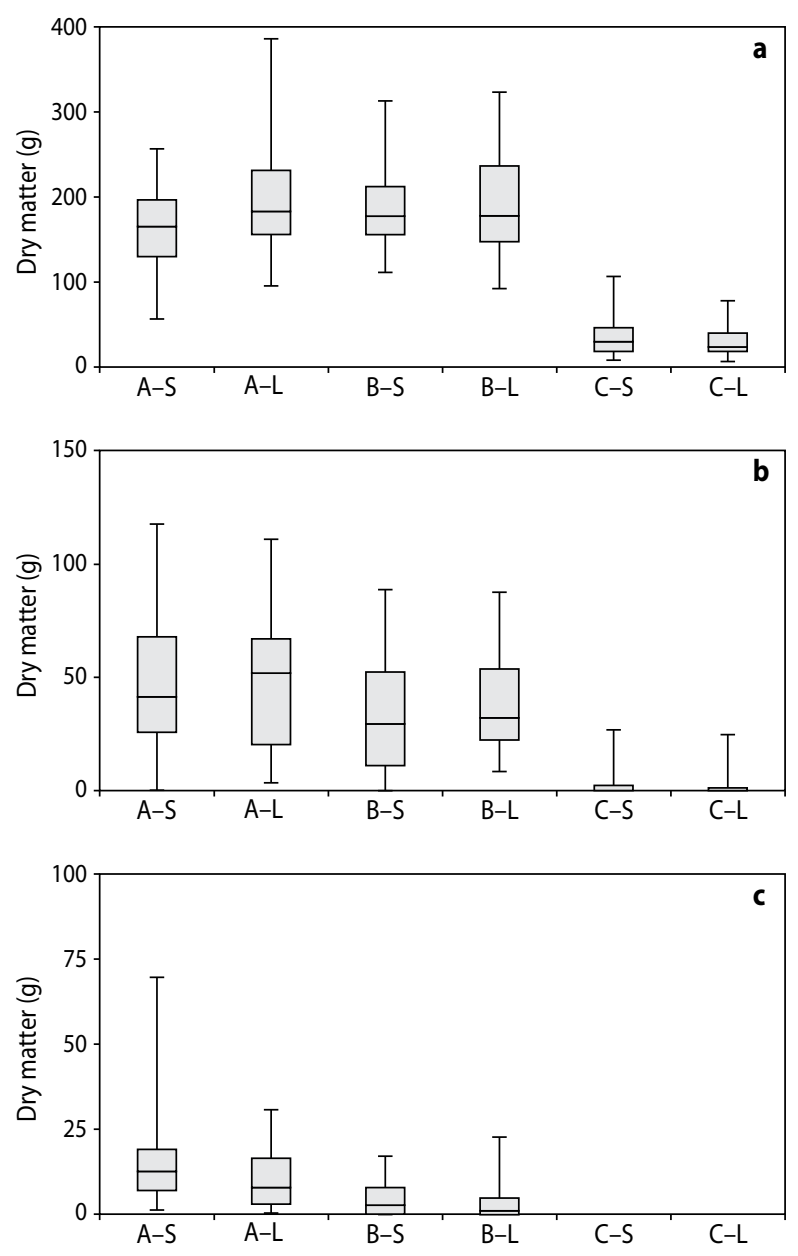

Figure 3. Total dry mass of sprout shoots of black cherry collected in the 2015 vegetation season - quartile method. Sprout generation response of trees cut or girdled: $a$ - in early spring, with three-time removal of sprouts; $b$ - in late spring, with two-time removal of sprouts; $\mathrm{c}$ - in the summer, with a one-time removal of sprouts. A = basal cut-stump, $\mathrm{B}=$ stem cut at the height of $1 \mathrm{~m}$ above the ground, $\mathrm{C}=$ stem girdling; $\mathrm{S}=$ Sieraków plot, $\mathrm{L}=$ Lipków plot

\section{Dying of trees after the procedure of mechanical elimination}

The application of basal cut-stump and of a cut at the height of $1 \mathrm{~m}$ in early spring combined with triple removal of sprouts did not contribute to killing any speci- 
mens of black cherry in the season when the procedure was carried out (Tab. 2). In the case of girdling, the symptoms of dying out (dead crown and lack of sprouts in the autumn control) were recorded in the case of every other tree in the Sieraków study plot and every fourth one in the Lipków study plot. A similar result was observed in the case of trees girdled in late spring, after double removal of sprouts - although in this case, there were more dead trees in the Lipków study plot than in the Sieraków one. In the case of the procedure carried out in summer, all trees treated with basal cut-stump and girdling survived in the first year of treatment, and only in the case of cutting at a height of $1 \mathrm{~m}$ did a part of the trees not sprout new shoots.

Table 2. Effectiveness of mechanical elimination of black cherry in the Kampinos National Park represented by the percentage of trees dying in the year of application of a treatment

\begin{tabular}{|c|c|c|c|c|}
\hline \multirow{3}{*}{ Treatment } & \multirow{3}{*}{ Location } & \multicolumn{3}{|c|}{ Dead trees* $(\%)$} \\
\hline & & \multicolumn{3}{|c|}{ Date of treatment } \\
\hline & & $\begin{array}{l}\text { Early } \\
\text { spring }\end{array}$ & $\begin{array}{c}\text { Late } \\
\text { spring }\end{array}$ & Summer \\
\hline \multirow{2}{*}{$\begin{array}{l}\text { Basal } \\
\text { cut-stump }\end{array}$} & Sieraków & 0 & 0 & 0 \\
\hline & Lipków & 0 & 0 & 0 \\
\hline \multirow{2}{*}{$\begin{array}{l}\text { Cut at a height } \\
\text { of } 1 \mathrm{~m}\end{array}$} & Sieraków & 0 & 8 & 4 \\
\hline & Lipków & 0 & 0 & 24 \\
\hline \multirow{2}{*}{ Girdling } & Sieraków & 52 & 32 & 0 \\
\hline & Lipków & 24 & 44 & 0 \\
\hline
\end{tabular}

* The trees that did not generate sprouts by the date of last removal (i.e., September 20th) in the 2015 vegetation season; in the case of girdled trees, their crowns were also dead.

\section{Discussion}

\section{Is girdling an effective method of eliminating black cherry in the conditions of central Poland?}

Each of the mechanical procedures of eliminating black cherry tested in this study stimulated the awakening of dormant buds and growth of sprout shoots in trees. The degree of the response depended on the type of activity and was noticeably and statistically significantly lowest in the case of girdled trees. The trees girdled in early spring generated about 4 times less sprout shoots than the trees cut at the same date. Reduction of sprouting capacity assessed by measurement of the three longest shoots and of the dry mass of shoots was significantly higher in the case of girdled trees. However, sprout shoots were present among all trees, and when they remained, the possibility that dead crown will be substituted by young shoots needed to be taken into consideration.

The trees girdled in early spring produced living leaves, even though cambium and phloem were cut in the phase when buds break (at the beginning of vegetation season). The first symptoms of the crowns' dying were recorded only in summer, and in autumn, the crowns of $62 \%$ of the trees were dead (mean from two study plots), and $20 \%$ suffered from decreased vitality. The high vitality of tree crowns throughout most of the vegetation season probably had a limiting impact on the sprouting capacity of stems below the girdle. The crowns, remaining after girdling, limited the penetration of sun to the damaged stem, while on the contrary, the cutting procedures created a clearing that allowed much more light into the bottom of the forest. Several studies show that black cherry reacts with intense growth to light supply (among other, Husch 1954; Starfinger 1997; Closset-Kopp et al. 2007). Therefore, a possibility of delayed sprouting response due to the awakening of dormant buds in the next vegetation season needs to be taken into consideration. Therefore, the experiment requires continuation, and the final conclusions will be possible only after another vegetation season. The need for caution in assessing the effectiveness of procedures in the first year was pointed out by Van den Meersschaut and Lust (1997).

In autumn of first year, the degree of dying out of trees girdled in early and late spring reached $24-52 \%$ depending on the study plot and date of procedure (Tab. 2). In response to the question stated in the objectives of this study, it must be said that based on the results obtained, girdling is not a completely effective method of eliminating black cherry; however, it is much more effective than basal cut-stump or cutting at a height of $1 \mathrm{~m}$ above the ground.

A high effectiveness of stem girdling the black cherry in comparison to felling and to a procedure that consisted of bending the stem combined with snapping the stem to cause an incomplete break of the cambium at a height of ca $80 \mathrm{~cm}$ was recorded in an experiment carried out in northern Italy (Annighöfer et al. 2012). After the vegetation season, the girdled trees 
did not differ from the control trees (not subjected to any procedure) with regard to the size and mass weight of the sprout shoots, but the number of sprouts was similar (between ten and twenty on average) to that of trees subjected to other procedures. Also, a comparison of effectiveness of chemical, biological and mechanical methods in an experiment carried out in Belgium showed that girdling brings the best results. With regard to the dates and number of additional procedures consisting of removal of sprouts, the percentage of dead trees in the second year of the experiment was between 35\% and 90\% (Van den Meersschaut and Lust 1997). These authors recommended girdling for application in environmentally sensitive areas (in nature reserves) where it is forbidden to use more effective chemical or biological methods. Some practitioners have expressed different opinions: based on active protection activities carried out in the Roztocze National Park, they assessed the girdling procedure as possessing low effectiveness, due to abundant sprouting below the girdle, high labour intensiveness and high requirements regarding the execution of girdle (Tittenbrun and Radliński 2015).

\section{Does application of cutting at a height of $1 \mathbf{~ m}$ above the ground limit sprouting capacity of black cherry?}

To limit the regeneration of black cherry, cutting stems at a height of $0.5-1 \mathrm{~m}$ above the ground has been tested in practical activities (Krzysztofiak and Krzysztofiak 2015; Tittenbrun and Radliński 2015). Cutting at a height of $1 \mathrm{~m}$ followed by systematic removal of sprouting shoots every couple of years is also practiced in the Kampinos National Park, on ca 1,000 ha of forest of the Rózin division (Namura-Ochalska and Borowa 2015). Activities consisting of systematically disturbing the black cherry to inhibit its growth, result in dying out of a part of the trees and radically reduce its generative breeding (Namura-Ochalska and Borowa 2015; Tittenbrun and Radliński 2015).

In this experiment, we raised the question of whether the application of cutting at a height of $1 \mathrm{~m}$ above the ground significantly reduces the sprouting response of affected trees. The obtained results show this procedure to demonstrate a slight reducing impact in comparison to basal cut-stump. A lack of statistically significant differences was seen for the number of sprout shoots at all three dates of procedures and for both study plots (Fig. 1). The reduction of dry mass of shoots was significant only for the summer cut (Fig. 2). High cutting had a reducing impact on the index of total length of three longest shoots; the difference was significant for four out of six combinations of the experiment (Fig. 3). The highest effectiveness of cutting at a height of $1 \mathrm{~m}$ - expressed both by the three parameters of sprouting capacity as well as by percentage participation of dead trees - was obtained only for the summer procedure. Further study will show whether this result will be maintained in the next vegetation season.

A slightly higher effectiveness of cutting at the height of $0.5-1 \mathrm{~m}$ than ours was obtained in Belgium. As a result of the procedure carried out in autumn with single or two-time removal of sprouts, a mortality of $22 \%$ and $31 \%$ was obtained, which then grew to $48 \%$ and $55 \%$ in the second year of experiment (Van den Meersschaut and Lust 1997). A different result from ours was obtained in a comparison of sprouting capacity of the three species: Acer spicatum Lam. (mountain maple), Betula papyrifera Marsh. (paper birch) and Prunus pensylvanica L. (pin cherry), cut at four heights: 0, 15, 45, and $75 \mathrm{~cm}$ (Jobidon 1997). After 2 years, the higher-cut stems had significantly more sprouts; however, these differences decreased with the following season of sprout generation and after 10 years, they ceased to be significant. That experiment, in contrast to our study, focused on much younger trees aged only three years.

Practitioners point out the convenience of distribution of sprouts in the higher part of damaged stem, from the perspective of enabling subsequent cuts. The study carried out here supports that opinion. Although sprouts were most frequently distributed along the whole of stem, they were most numerous and reached the greatest sizes in the higher parts of stems (field observation).

\section{Impact of cutting and sprout removal on stimulating the regeneration of black cherry}

The results obtained confirm known studies showing a strong sprouting response by black cherry to cutting. This undermines the reasons for its application as a method of limiting this species' invasion (among others, Marquis 1990; Starfinger et al. 2003; Halare- 
wicz 2012; Namura-Ochalska 2012; Annighöfer et al. 2012). The repeated (three times per season) removal of sprouts was aimed at causing the trees to die out, as had taken place in the experiment carried out in Belgium (Van den Meersschaut and Lust 1997). The application of 2-3 additional procedures for two following years also resulted in high mortality of cut trees in studies carried out by Van der Kruis (1990 after Van den Meersschaut and Lust 1997). However, in the first vegetation season of our experiment, no specimen cut in early spring at the base or at a height of $1 \mathrm{~m} \mathrm{died.}$ Sprout removal contributed, on the other hand, to the awakening of dormant buds and growth of sprouts. The highest number of sprout shoots was recorded during the first control, while the number dropped with the repetition of procedure. The method of carrying out the experiment made it possible to take into account the measurements of all sprouts, while leaving sprouts without stripping leads to natural elimination of some of them (Annighöfer et al. 2012). In Italy, black cherries similar to those in our experiment, growing under the canopy and characterised by a similar girth, produced on average 36 sprouts (+- SD 21) after one year from cutting (Annighöfer et al. 2012), while we obtained a total of on average 103 sprouts (+- SD 52) from three controls in the Sieraków study plot and on average 99 sprouts (+- SD 34) in the Lipków study plot (Fig. 1a).

Due to a very strong sprouting response by black cherry to mechanical damage, it is necessary to consider extraction and removal of the root. This procedure brings noticeably better results, but it is much more time-consuming and difficult to carry out in vast areas. The introduction of indigenous tree species as competition for black cherry is also an effective method of limiting the occurrence of this neophyte (Starfinger et al. 2003; Otręba et al. 2014; Namura-Ochalska and Borowa 2015).

\section{Conclusions}

In the habitat conditions of central Poland, stem-girdling of black cherry has proven to be a significantly more effective method of elimination than basal cutstump or cutting at a height of $1 \mathrm{~m}$ above the ground. Nonetheless, in the season of applying the procedure, even with additional procedures of sprout removal, only a part of the girdled trees died out (24-52\%). Thus, even the procedure of girdling was not effective in the first year of experiment. The procedure of stem cutting at a height of $1 \mathrm{~m}$ from the ground only partially limited the sprouting response of the trees. The number of sprouts on the trees cut at the base and at a height of $1 \mathrm{~m} \mathrm{did}$ not differ statistically significantly. High cutting, on the other hand, did limit the total length of the three strongest shoots. Despite application of additional procedures of removal of sprouts, all trees cut in early spring maintained vitality in autumn of the first year of experiment. For all tested procedures, it is possible to observe an increase in their effectiveness in limiting sprouting capacity (to $100 \%$ in the case of girdling) with a later date of applying the procedure.

The number of repetitions of the sprout-shoot removal procedure needed to cause complete death (and in consequence, elimination) of a tree is an important piece of information for use in practical elimination of the black cherry. However, observations carried out in one vegetation season cannot be treated as conclusive. The continuation of experiment in the following year is necessary for a complete and reliable assessment of the effectiveness of both the tested methods, as well as the dates of their application and the number of repetitions. Only then will it be possible to evaluate the actual effectiveness of applied procedures of mechanical elimination of black cherry in the Kampinos National Park.

Due to the high sprouting response by black cherry to mechanical damage, in areas of environmental value it seems worthwhile to consider application of more time-consuming and costly methods, such as extraction and root removal, as well as the planting of competitive indigenous species with the goal of eliminating black cherry.

\section{ACKNOWLedgements}

The authors wish to thank Jakub Górski for his assistance in the field and help with the graphic presentation of data, Piotr Zaniewski for statistical analyses and graphic presentation of data and Michał Główka for help provided during all field work. We express our gratitude to Przemek Kurek and Blanka Wiatrowska for their work on laying the grounds for this experiment. 
Research funded by the forestry fund of Polish State Forests under contract no. EZ. 0290.1.18.2015.

\section{References}

Andrzejewska A. 2003. Climate (in Polish with English summary). In: The Kampinos National Park. Volume 1. Nature in the Kampinos National Park (ed.: R. Andrzejewski). Kampinoski Park Narodowy, Izabelin, Poland, 41-67.

Andrzejewska A., Ferchmin M., Kebłowska A., Otręba A. 2010. Geobotanical characterisation of the Kampinos Forest (in Polish with English summary). In: From Masovia to Polesie and the Vilnius Region. Diversity and Protection of the Vegetation of the Borderland of Central and Northeastern Europe (ed.: A. Obidziński). PTB Zarząd Główny, Warszawa, Poland, 41-56.

Annighöfer P., Schall P., Kawaletz H., Mölder I., Terwei A. 2012. Vegetative growth response of black cherry (Prunus serotina) to different mechanical control methods in a biosphere reserve. Canadian Journal of Forest Research, 42 (12), 2037-2051.

Bijak S., Czajkowski M., Ludwisiak L. 2014. Occurrence of black cherry (Prunus serotina Ehrh.) in the State Forests in Poland (in Polish with English summary). Leśne Prace Badawcze, 75 (4), 359-365.

Bomanowska A., Kirpluk I., Adamowski W., Palus J., Otręba A. 2014. The Problem of invasions of alien plants in Polish national parks (in Polish with English summary). In: Invasive plant species in the Kampinos National Park and its neighbourhood (eds.: A. Otreba, D. Michalska-Hejduk). Kampinoski Park Narodowy, Izabelin, Poland, 9-14.

CBD. 1992. Convention on Biological Diversity. http:// www.cbd.int. Accessed 1.10.2016.

Closset-Kopp D., Chabrerie O., Valentin B., Delechapelle H., Decocq G. 2007. When Oskar meets Alice: Does a lack of trade-off in r/K-strategies make Prunus serotina a successful invader of Europan forests? Forest Ecology and Management, 247, 120-130.

Csiszár Á., Korda M. 2015. Summary of invasive plant control experiments. In: Practical experiences in invasive alien plant control (eds.: Á. Csiszár, M. Korda). Duna-Ipoly National Park Directorate, Budapest, Hungary, 203-235.
DAISIE. Delivering Alien Invasive Species Inventories for Europe. http://www.europe-aliens.org. Accessed 03.02.2014.

Demeter L., Lesku B. 2015. Eradication of invasive alien plants in the southern Nyírség area of the Hortobágy National Park Directorate. Practical experiences in invasive alien plant control (eds.: Á. Csiszár, M. Korda). Duna-Ipoly National Park Directorate, Budapest, Hungary, 75-80.

Halarewicz A. 2012. Ecological traits and the consequences of dispersal of black cherry, Padus serotina (Ehrh.) Borkh. in selected forest phytocenoses (in Polish with English summary).Wydawnictwo Uniwersytetu Przyrodniczego we Wrocławiu, Wrocław, Poland.

Hammer Ø., Harper D.A.T., Ryan P.D. 2001. PAST: Paleontological Statistics software package for education and data analysis. Paleontologia Electronica, 4 (1), 1-9.

Husch B. 1954. The regeneration of Prunus serotina in Northwestern Pennsylvania following cutting. Ecology, 35 (1), 11-17.

Jobidon R. 1997. Stump height effects on sprouting of mountain maple, paper birch and pin cherry 10 year results. The Forestry Chronicle, 73 (5), 590-595.

Krzysztofiak L., Krzysztofiak A. 2015. Protection of native flora from alien plant species in the areas of Natura 2000 "Ostoja Wigierska", "Sandr Brdy" i "Roztocze Środkowe" (in Polish). In: Invasive alien species as a danger to native nature (eds.: L. Krzysztofiak, A. Krzysztofiak). Stowarzyszenie “Człowiek i Przyroda", Krzywe, Poland, 9-18.

Marquis D.A. 1990. Prunus serotina Ehrh. black cherry. In: Silvics of North America. Vol. 2. Hardwoods. Agricultural Handbook 654 (eds.: R.M. Burns, B.H. Honkala). U.S. Department of Agriculture, Forest Service, Washington DC, USA, 238-249.

Matuszkiewicz W. 2001. Guide to identification of plant communities of Poland. Wydawnictwo Naukowe PWN, Warszawa, Poland.

Muys B., Maddelein D., Lust N. 1992. Ecology, practice and policy of black cherry (Prunus serotina Ehrh.) management in Belgium. Silva Gandavensis, 57, $28-45$.

Najberek K., Solarz W. 2011. Biological invasions in the Polish national and landscape parks (in Polish 
with English summary). In: Alien species in the fauna of Poland (eds.: Z. Głowaciński, H. Okarma, J. Pawłowski, W. Solarz). Instytut Ochrony Przyrody PAN, Kraków, Poland, 624-639.

Namura-Ochalska A. 2012. Elimination of American bird cherry Padus serotina - assessing the effectiveness of selected methods in the Kampinos National Park (in Polish with English summary). Studia i Materialy Centrum Edukacji Przyrodniczo-Leśnej, 33 (4), 190-200.

Namura-Ochalska A., Borowa B. 2015. The struggle against black cherry Padus serotina (Ehrh.) Borkh. in the Forest Division Rózin of the Kampinos National Park; Assessment of the effectiveness of selected methods (in Polish). In: Invasive alien species as a danger to native nature (eds.: L. Krzysztofiak, A. Krzysztofiak). Stowarzyszenie "Człowiek i Przyroda”, Krzywe, Poland, 127-142.

Otręba A., Kurek P., Wiatrowska B. 2014. Programme for elimination of invasive alien tree species in the Kampinos National Park - extent and effectiveness (in Polish with English summary). In: Invasive plant species in the Kampinos National Park and its neighbourhood (eds.: A. Otręba, D. MichalskaHejduk). Kampinoski Park Narodowy, Izabelin, Poland, 89-97.

Plan for protection of forest ecosystems of the Kampinos National Park for the period 1.01.2002-21.12.2021 (in Polish). 2002 . Biuro Urządzania Lasu i Geodezji Leśnej w Warszawie, Warszawa, Poland, manuscript.

Regulation (EU) No 1143/2014 of The European Parliament and of the Council of 22 October 2014 on the prevention and management of the introduction and spread of invasive alien species.

Stanisz A. 2006. An accessible course in statistics with the application of STATISTICA PL with examples in medicine (in Polish). Statsoft, Poland.
Starfinger U. 1997. Introduction and naturalization of Prunus serotina in Central Europe. In: Plant invasions: studies from North America and Europe (eds.: J.H. Brock, M. Wade, P. Pyšek, D. Green). Backhuys Publishers, Leiden, Netherlands, 161-171.

Starfinger U., Kowarik I., Rode M., Schepker H. 2003. From desirable ornamental plant to pest to accepted additional to the flora? - the perception of alien tree species through the centuries. Biological Invasions, 5, 323-335.

Tittenbrun A., Radliński B. 2015. Practices of eliminating alien invasive species in the Roztocze National Park (in Polish). In: Elimination of invasive alien species - good and bad practices (eds.: L. Krzysztofiak, A. Krzysztofiak). Stowarzyszenie "Człowiek i Przyroda", Krzywe, Poland, 49-54.

Tokarska-Guzik B. 2005. The establishment and spread of alien plant species (kenophytes) in the flora of Poland. Wydawnictwo Uniwersytetu Śląskiego, Katowice, Poland.

Tokarska-Guzik B., Dajdok Z., Zając M., Zając A., Urbisz A., Danielewicz W., Hołdyński C. 2012. Alien plants in Poland with particular reference to invasive species (in Polish with English summary). Generalna Dyrekcja Ochrony Środowiska, Warszawa, Poland.

Van den Meersschaut D., Lust N. 1997. Comparison of mechanical, biological and chemical methods for controlling black cherry (Prunus serotina) in Flanders (Belgium). Silva Gandavensis, 62, 90-109.

Van der Kruis A. 1990. De ontwikkeling van natuurlijke warden in bossen op zandgronden (in Dutch). Stichting Kritisch Bosbeheer, Nijmegen, Netherlands.

Vanhellemont M. 2009. Present and future population dynamics of Prunus serotina in forests in its introduced range. Ph. D thesis, Ghent University, Ghent, Belgium. 